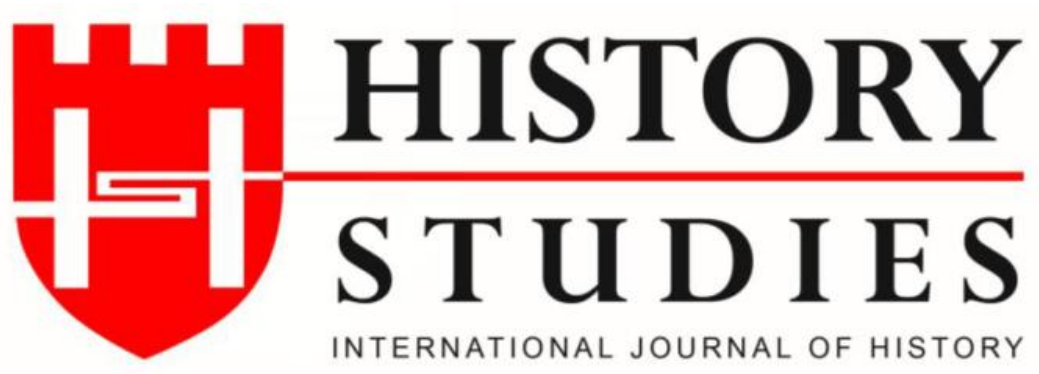

ISSN: 13094173 (Online) 1309 - 4688 (Print)

Volume 12 Issue 3, June 2020

DOI Number: 10.9737/hist.2020.869

Araştırma Makalesi

Makalenin Geliş Tarihi: 26.04.2020 Kabul Tarihi: 25.05.2020

Atıf Künyesi: Merve Suna Özel Özcan - Hatice Çelik, “An Analysis of Turkish-American Relations

from a Historical Perspective", History Studies, 12/3, Haziran 2020, s. 1095-1111.

\title{
An Analysis of Turkish-American Relations from a Historical Perspective
}

\author{
Tarihsel Süreçte Türk-Amerikan İlişkilerinin Analizi \\ Dr. Merve Suna Özel Özcan - Dr. Hatice Çelik \\ ORCID No: 0000-0001-9027-3990 / 000-0003-1409-8865 \\ Kırıkkale Üniversitesi / Ankara Sosyal Bilimler Üniversitesi
}

\begin{abstract}
The historical depth of relations between the United States of America (USA) and the Turks dates back to the Ottoman Empire period. The Ottoman-American relations were conducted mostly through economic linkages in the $19^{\text {th }}$ century. With the dissolution of Ottoman Empire, Republic of Turkey (Turkey) has been the successor and the relations with the USA has been reoriented as being the nation-state at the new international system level. Although relations between these two countries were interrupted occasionally, following the World War II, they were seen to remain unbroken. Basically, the strategic partnership formed in the axis of common enemy perception and interests during the Cold War period was a kind of transformation of the relations coming from the Ottoman times since during the Ottoman era, relations were mostly economy based. As a matter of fact, Turkey-USA relations, which show an ups and downs picture from the 1950s to the present day, continue uninterrupted. In this regard, the evaluation of the relations between the two countries will be discussed in this study over certain crisis issues.
\end{abstract}

Keywords: Turkey, US, Ottoman Empire, Cold War

Öz: Amerika Birleşik Devletleri ve Türklerin ilişkilerinin tarihi derinliği Osmanlı İmparatorluğu dönemine kadar uzanmaktadır. Osmanl1-Amerikan ilişkileri çoğunlukla 19. yüzyılda ekonomik bağlar yoluyla yürütülmüştür. Osmanlı İmparatorluğu'nun dağılmasıyla birlikte Türkiye Cumhuriyeti (Türkiye) Osmanlı'nın halefi olmuştur ve ABD ile ilişkiler yeni uluslararası sistem düzeyinde ulus-devlet olarak yeniden şekillendirilmiştir. Bu iki ülke arasındaki ilişkiler ara sıra kesintiye uğrasa da, II. Dünya Savaşı'ndan sonra, kesintisiz olarak sürdürülmüştür. Temel olarak, Soğuk Savaş döneminde ortak düşman algısı ve çıkarları ekseninde oluşan stratejik ortaklık, Osmanlı döneminden gelen ilişkilerin bir tür dönüşümü idi, çünkü Osmanlı döneminde ilişkiler çoğunlukla ekonomiye dayanıyordu. Nitekim 1950'lerden günümüze kadar inişler ve çıkışlar gösteren Türkiye-ABD ilişkileri kesintisiz devam etmektedir. Bu bağlamda, bu çalışmada iki ülke arasındaki ilişkilerin belirli kriz dönemlerinde değerlendirilmesi tartışılacaktır. Burada değinilen dönem, iki ülke arasındaki ilişkileri kapsayan yaklaşık yüz yıllık süre olup, Soğuk Savaş dönemindeki krizlere özellikle değinilecektir.

Anahtar Kelimeler: Türkiye, ABD, Osmanlı İmparatorluğu, Soğuk Savaş 


\section{Introduction}

The Order of Versailles, which was created at the end of World War I, created an atmosphere of peace in which both the Middle East and Europe were hanging by a thread. This system having weaknesses from the very beginning, was broken with the entry of Germany into Poland on 1 September 1939 and the world was dragged into a new war. The United States of America (USA) and the Union of Soviet Socialist Republics (USSR) acted together in the war against the aggressive positions and expansionist policy of the Axis powers, especially Hitler's Germany. In the period following the end of World War II, the differences in the policies and ideologies that the USA and USSR pursued in Berlin led to the beginning of the Cold War period, which would last until the collapse of the Berlin Wall in 1989, which the USSR built to separate its occupation zone, and the unification of the two separate states, Federal Germany and Democratic Republic of Germany in 1990.

The relations between Turkey and the United States have followed a bumpy course in the historical process. Indeed, this bumpy process has revealed a degree of attachment in the form of a strict alienation of relations between the two countries but never severing. In this context, it can be suggested that during periods of alienation, not only Turkey but also the United States have developed new common pursuits. At the last point, the relations between the two countries, which have been read through the strategic environment in the past, have come to a point of divergences during the Cold War.

In this study, the relations between Turkey and the United States began in the period of the Ottoman Empire will be the starting point. After this, it will be examined in the Cold War process following World War II. In this context, mainly the Cuban crisis, the Johnson letter and Cyprus issue-related conjuncture of the relations will be tried to analyse from a historical perspective. In line with this analysis, it is argued that although the relations between Ottoman and the US conducted via economic and trade linkages, with the dissolution of Ottoman and founding of Turkey has changed this character. Now as being two nation-states, the US and Turkey defined their relations more on the basis of security, strategy and military alliance especially in the Cold War era.

\section{Ottoman Empire and the U.S. Relations}

When it is looked at the basis of U.S. and Turkish relations, especially the Ottoman Empire period is a remarkable process. In particular, there are two fields in the relations between these two starting from the 18th century till the 20th century: those were economic\&trade relations and missionary activities. Ottoman Empire which was founded at the end of the 13th century and started to increase its power in the seas, the Mediterranean and Red Sea were dominated by the Ottomans. It is worthnothy at this point that the Ottoman advance in the seas led it to seek to see different regions, and during the $15^{\text {th }}$ century it had gone to the east cost of the USA. In addition, it is known that the first to discover the "Great Turkish archipelago" in the east cost of the United States were Turkish sailors. In this context, it is argued that Columbus went to America by using sea routes maps made by Turks and Muslims and, but the West concealed this. As a matter of fact, following this historical transition, it is seen that the Ottoman Empire 
faced a number of problems in the period corresponding to the founding of the United States. ${ }^{1}$ Especially during this period, developments such as the Ottoman-Russian Wars and the impacts of the French Revolution on the Empire were blended with the financial and administrative problems experienced in the empire.

It is seen that the basic focus of Ottoman and American relations is trade. In particular, the Mediterranean region under the control of the Ottoman Empire stands out as an important part of the commercial activities of the United States. It was thanks to Britain that Ottoman and USA relations began in the commercial field and since the $17^{\text {th }}$ century, American ships have entered Turkish ports under the auspices of the British. The first point of encounter between the Ottomans and the United States was the Maghreb. ${ }^{2}$ In 1786, the United States signed agreements with Algeria and Tunisia, the originals of which were in Turkish, and the right of U.S. ships to trade freely in the region was granted in the Garp Ocaklar1 ${ }^{3}$. Thus, the United States essentially ensured the safety of its ships in the Western Mediterranean by making agreements with the states of Algeria, Tunisia, Morocco and Tripoli, called Garp quarries, Maghreb quarries and Berber quarries. The fact that the Ottoman Empire had a large area on three continents gave rise the USA to turn to this geography geostrategically and geopolitically. ${ }^{4}$ In this redard, Izmir was an important center in trade relations between the Ottoman Empire and the US. In addition, with the advancement of bilateral relations, in early 1828, the Ottoman government allowed the American ships to pass through the Dardanelles in the contex of "out of friendly considerations". 5

American- Ottoman Trade

\begin{tabular}{|c|c|}
\hline \multicolumn{2}{|c|}{ American- Ottoman Trade } \\
\hline American Exports & Armerican Imports \\
\hline 1,741 cases opium & 13,218 bags coffee \\
\hline 1,580 kintals boxwood & 1,448 hds. rum \\
\hline 12,000 metticals* rose oil & $182 \cdot$ bags pepper \\
\hline \multicolumn{2}{|l|}{2,739 cases raisins } \\
\hline \multicolumn{2}{|l|}{76,455 drums figs } \\
\hline \multicolumn{2}{|l|}{26,150 okkas old copper } \\
\hline \multicolumn{2}{|l|}{ 13,582 kilos salt } \\
\hline \multicolumn{2}{|l|}{1,325 drums Suitana raisins } \\
\hline \multicolumn{2}{|c|}{$\begin{array}{l}\text { one mettical = } 4.64 \text { grams; one okka= } 1.28 \text { kilograms) } \\
\text { See: Concular Letters, Smyrna, Offley to Martin Van Buren, } 4 \text { February 1850. (Akt: } \\
\text { A. Üner Turgay "Ottoman- American Trade Durıng The Nineteenth Century", Ed. } \\
\text { Halil İnalcık - Nejat Göyünç Heath W. Lowry, The Journal Of Ottoman Studies } \\
\text { III,İstanbul,1982,s 200) }\end{array}$} \\
\hline
\end{tabular}

Despite the "Monroe Doctrine", which the United States declared in 1823 following its emergence on the historical stage, it is an important detail that it also operated outside the American continentss. One year after the declaration of the Monroe Doctrine, the United States began to focus heavily on its relations with the Ottoman Empire. At this point, Bostanoğlu

\footnotetext{
${ }^{1}$ Ayrıntılı bilgi için bkz: Mustafa Bıyıklı, Türk Dış Politikası Cilt: I, Gökkube Yayınları, İstanbul, 2008, ss.380-385.

${ }^{2}$ For further details: Burcu Bostanoğlu, “Amerika ve Osmanlı'nın Akdeniz'de Başlayan Seyir Defteri”, Doğu Batı Yayınları, Say1: 42, 2007, ss. 213-228.

${ }^{3}$ The definition is used for the Ottoman-dominated Algeria, Tripoli and Tunisia provinces. ( For Further details. Atilla Çetin, "Garp Ocakları", İslam Ansiklopedisi, (Erişim: https://islamansiklopedisi.org.tr/garp-ocaklari)

${ }^{4}$ Burcu Bostanoğlu, Türkiye-ABD İlişkilerinin Politikası, İmge Kitabevi, Ankara, 2008, s.353-359 (For furthe details: Erhan, Çağrı, Türk-Amerikan Illişkilerinin Tarihsel Kökenleri, İmge Kitabevi, Ankara, 2015)

5 A. Üner Turgay "Ottoman- American Trade During The Nineteenth Century", Ed. Halil İnalcık - Nejat Göyünç Heath W. Lowry, The Journal Of Ottoman Studies III, İstanbul,1982, s 200.
} 
points out that the United States sees the Ottoman Empire as the "key to the East" and as a result tries to improve its trade relations. ${ }^{6}$ Thus it is possible to say that the United States continued to operateits Monroe Doctrine "isolation policy" with a certain degree of restraint until the $20^{\text {th }}$ century. While avoiding to be a part of European political affairs, the United States has simultaneously moved to develop and direct its trade relations, which can be considered as one of the most important steps to be taken by a newly formed state.

On the other hand, especially by the end of the $18^{\text {th }}$ century, the Ottoman Empire became the focus of the European powers in the international system and the existence of the Russian Empire as a threatin the north, led to the search for establishment of new alliances. The Navarin incident at this point is one of the developments of particular note. In 1827, the Ottoman navy was destroyed in Navarin by the alliesconsisting of French, British and Russian ships. Upon this event, the Sultan II. Mahmoud of the period moves away from the West while there is seen no problem in relations with the United States. On May 7, 1830, Treaty of Seyr-I Sefain was signed by the Ottoman andthe United States and American merchants and merchant ships were given the status of "most favored state". The Ottoman Empire's interest in American warships and land weapons paved the way for a tight arms trade between the two countries. Diplomatic relations werealso initiated one step after increasing trade relations. ${ }^{7}$ In 1831 , Commodore David Porter was appointed as charge d'affaires in Istanbul by the USA. ${ }^{8}$ With the Tanzimat of 1839, US experts also trained in agriculture and mining in Istanbul, while Henry Eckworth, the ship's engineer, is also known to have directed the construction of American model warships. However, due to diplomatic relations between the two countries, mutual embassies could only be opened in $1867 .{ }^{9}$

When we look at the missionary activities in Ottoman - US relations, it will be seen that the process has shifted from commercial relations to social and political fields. The United States, like many European states, enjoyed capitulations and privileges under the agreements made between the Ottoman Empire and the United States. Erhan emphasizes two points concerning the spread of missionary in the Ottoman Empire. These are mission stations and missionary schools. While missionary activities were based in Istanbul within the Empire, mission stations started to be opened in Asia and Europe. ${ }^{10}$

Here it is necessary to give a brief overview of U.S. foreign policy and its fundamentals. In the context of the "WASP"11 idea in American foreign policy, it is seen that nations are divided

\footnotetext{
${ }_{7}^{6}$ Bostanoğlu, age. s.535

${ }^{7}$ In 1851, Major Emin Bey presented a report to Captain-I Derya Pasha after visiting the important shipyards of the United States. Following this report, Bab-i Ali decided to place new orders. However, in 1858, as a result of the intensive diplomatic effort of the British ambassador, this order was granted to the United Kingdom. Indeed, the Ottoman Empire imported American land weapons for the first time in 1865. ( Turgay, age. ss.189-246.)

${ }^{8}$ Bostanoğlu, agm, s. 221.

${ }^{9}$ Bostanoğlu, age. s. 353-359.

${ }^{10}$ Çağrı Erhan, "Ottoman Official Attitudes Towards American Missionarie"s , s.326.(Erişim : http://intcommunity.org/wp-content/uploads/2018/02/Ottoman_Official_Attitudes-Cagri_Erhan.pdf)

${ }^{11}$ This acronym, which stands for "White Anglo-Saxon Protestant", is described in the Cambridge Dictionary as: "a white American whose family originally came from Northern Europe and was accordingly part of the group considered to have the most influence and the most money in American society." ("WASP", https://dictionary.cambridge.org/tr/s\%C3\%B6zl\%C3\%BCk/ingilizce/wasp)
} 
into three by the eyes of an elected Protestant, white American. This distinction provided a legitimate ground for the missionary activities of the United States. From the idea that nations are divided into three, a distinction has been made between Wasps, who are thought to have the power to govern others, and those who are able to govern themselves and the ones that are not able to do either. In this regard, WASP has intensified its efforts to have a control over the Ottoman Empire by accelerating its opening missionary and educational institutions. Thus, the United States, acting on the basis of this idea, directed its concessions to the field of education. With the steps of the United States especially in the field of education, missionary activities gained momentum, too. The American Board of Commissioners for Foreign Missions (Amerikan Misyoner Teşkilatı) aimed to spread their Christian faith in the Middle East by opening schools instead of churches. ${ }^{12}$

Commercial and diplomatic relations between the two countries, which had been running smoothly between 1867 and 1901, had a short-lived break during the War of Independence. ${ }^{13}$ The system and actors changed with the First World War, which took place between 1914 and 1918. In this process, when the world history and the international system was about to change and empires are approaching their end, new nation-state structures werebeginning to take their place in the system. At this point, our work will take two things as units of analysis: the change that occurred at the system and state level and the Republic of Turkey's place in the international system as the successor state of the Ottoman Empire in line with the relations of the USA.

The formation of an order in the system that was created by the end of the First World War which not every state was satisfied with, soon brought the world into the Second World War between 1939 and 1945. The World War II period has been a new test for Turkey. After 1945, Turkey tried to findits place between the blocks led by the United States and the Union of Soviet Socialist Republics (USSR) within the bipolar world system. Until the late $19^{\text {th }}$ century, it is not possible to say that there was geopolitical relationship between the US and the Ottoman Empire; however, Second World War resulted in a change of the international environment in which the Turkish Straits became more significant for the Soviet Union. ${ }^{14}$ Due to this Soviet interest for the Straits which can be seen as a matter of life or death for Turkey, Turkey started to perceive USSR as a threat. Since Turkey choosed to be closer to the USA camp, Turkey took part in the Western bloc under the leadership of the United States against the threat of the USSR. Related to this choice, relations with the United States were intensified.

\section{Turkey-United States relations: The Early Cold War period}

With the First World War and the subsequent war of Independence, the Republic of Turkey has taken its place in the system as the new actor of the international field. The role and position of this newly formed state within the system, as well as its geostrategic strength and the challenges it faces are remarkable. In this context, it will be useful to define power first.

\footnotetext{
${ }^{12}$ Bostanoğlu, age, s.355

${ }^{13}$ Bülent Alirıza, Bülent Aras, U.S.-Turkish Relations: A Review At The Beginning of The Third Decade of The Post-Cold War Era, CSIS, November 2012, s.1

${ }^{14}$ Ayşe Ömür Atmaca, "The Geopolitical Origins of Turkish-American Relations: Revisiting the Cold War Years", All Azimuth, Vol.3, No.1, Jan. 2014, s.20
} 
Because while the nature of the international system has changed, power capacities have also become part of a new process. According to Nye power is "the ability to influence the behavior of others to get the outcomes one wants". So, he categorises it I) you can coerce them with threats, ii) you can induce them with payments and iii) or you can attract or co-opt them. ${ }^{15}$

Oran pointed out that the similarity between the Ottoman Empire and the Republic of Turkey manifested itself in the foreign policies of the two states. Because this successive state, as a medium-sized state ${ }^{16}$ established with the same people in the same geography, carried out their foreign policies with the principles of balance of power and non-entry into wars with other states if there was no threat of invasion. ${ }^{17}$ Altough the concept "middle-medium" is already a relatively defined one like "power"; nevertheless, Turkey, independent from its changing foreign policy agenda from government to government is usually defined as a medium-sized state.

However, according to Oran, the Ottoman Empire acted on the principle of not change either within the aspects of its own structure or within the international system, while the Republic of Turkey acted on the principle of change either within its own territorial aspects or within the international environment. ${ }^{18}$ At this point, we can see that these principles and practices are prominent in Turkish foreign policy, especially during the Cold War period. As a matter of fact, due to the changes in the international system, the main point of Turkish foreign policy to gain a place in the balance of power and the search for an alliance group was created in this period based on the security and threat dilemma.

Therefore, following the World War II, a new political and ideological order, began to dominate the world. Within this new world order, there were two main blocs that many states felt to become a part of either bloc as a compulsory action. ${ }^{19}$ Those blocs were the Eastern bloc, dominated by communist ideology, and the Western bloc, formed by states under the capitalist order. The direct unarmed conflict between the Soviet Union, which led the Eastern Bloc, and the United States, which led the Western bloc, was the most important feature of the Cold War. ${ }^{20}$ In this context, power relations instead of diplomacy began to be used as a method in inter-state relations during the Cold War period. In Churchill's words, there is now an "iron curtain" between East and West. During this period which continued till the destruction of the Berlin Wall in 1989, not only did technologies compete but also the states were in a race in economic terms in parallel with technological development. In this respect, the Easttried to respond to Western capitalism with its Communist economic order. ${ }^{21}$

\footnotetext{
${ }^{15}$ Joseph Nye, "The Benefits of Soft Power”, (Erişm: https://hbswk.hbs.edu/archive/the-benefits-of-soft-power)

${ }^{16}$ For a detailed categorization of middle/medium sized powers see: Hatice Çelik, "Middle Power Theory Literature: The Case of South Korea”, I. Uluslararası Insan Ve Toplum Bilimleri Kongresi Kitabı, Ankara, 2017, s. 19.

${ }^{17}$ Baskın Oran, "Türk Dış Politikasının Teori ve Pratiği”, Ed. Baskın Oran Türk Dış Politikası (Cilt1 1919-1980), İletişim Yayınları, İstanbul, 2009, s 19.

${ }^{18}$ Oran, agm., s 19.

${ }^{19}$ Fahir Armaoğlu, 20. Yüzyıl Siyasi Tarihi, Alkım Yayınları, Ankara, 2005, ss.419-422.

${ }^{20}$ Mustafa Ekincikli, İnönü-Bayar Dönemleri Türk Dış Siyaseti, Berikan Yayınları, 2001, s. 92.

${ }^{21}$ Oral Sander, Siyasi Tarih 1914-1994, İmge Kitabevi, İstanbul, 2005, s.225.
} 
The balance of power between the United States and the USSR presented a system that contained the struggle for supremacy. The formation of the bipolar world is mainly a process that began with the financial assistance of the United States to Turkey and Greece within the framework of the declaration of The Truman Doctrine. This is followed by the cration of economic and military structures with the Marshall Plan and the establishment of NATO. In response to the containment and security policies of the United States, the USSR similarly set out to create the Warsaw Pact in the military sphere and the COMECON in the economic sphere with the Eastern European countries. The military pacts created and the perception of security threats of the states against each other initiated a rapid armament process during the Cold War period. Armament shifted from conventional weapons area to the axis of nuclear weapons and technology, and on 23 August 1949, the USSR detonated its first atomic bomb becoming the second nuclear power. ${ }^{22}$

With the discourse of "iron curtain" 23 of Churchill, there emerged the two-bloc structure in the international system and this resulted in the fact that Turkey looked for its place within this structure. Uslu states that the main reason for bringing the United States and Turkey together in an alliance system is the Soviet Union. Since the USSR constantly made threats to Turkey such as; "The Soviet rulers unilaterally annulled the Friendship Treaty of 1925 between Turkey and the USSR, demanded changes in the Montreux Convention of 1936 in favor of the states bordering the Black Sea and demanded territory in eastern Anatolia, this forced the Turkish leaders to gain the military and diplomatic support of the United States". ${ }^{24}$ Thus, the 400-year history of relations between the Russians and the Ottomans has become even more problematic on the claims of the Soviets over the Straits and Eastern Anatolia. ${ }^{25}$

On the other hand, this situation was not one-sided. Turkey was drawing an important ally profile in the Middle East for the United States. Turkey has been seen as having an important power and role in ensuring thestability in an unstable geography. In this context, Turkey has played an active role in the international arena in the new order formed after World War II. Relations between the United Statesanother important actor of the bipolar system- and Turkey, were put in a framework starting with the "Truman Doctrine" of U.S. President Truman on March 12, 1947 which guaranteed the security of Turkey against the Soviet Union. This doctrine became the most important factor determining the Turkish foreign policy in Cold War era. Turkey, which served as a buffer against the Soviet Union's expansion into the Middle East and the Eastern Mediterranean during the nearly 45-year Cold War period, has therefore pursued a "west-oriented" policy. ${ }^{26}$

On the other hand, the two international superpowers have advanced through containment policies and international agreements in terms of establishing new imperial areas of expansion

\footnotetext{
${ }^{22}$ Mehmet Gönlübol, Uluslararası Politika, AÜSBF Yayınları, Ankara, 1985( 3. Baskı), s. 482.

${ }^{23}$ Çağrı Erhan, “ABD ve NATO'yla İlişkiler”, Ed. Baskın Oran Türk Dış Politikası (Cilt1 1919-1980), İletişı̇m Yayınları, İstanbul, 2009. s. 536.

${ }^{24}$ Nasuh Uslu, “1947'den Günümüze Türk-Amerikan İlişkilerinin Genel Portresi”, Avrasya Dosyası ABD Özel Saylsl, s.204. (Erişim: https://www.21yyte.org/assets/uploads/files/203-232\%20nasuh\%20uslu.PDF)

${ }_{25}$ CRS, "Turkey-U.S. Relations: Timeline and Brief Historical Context", (Erişim: https://fas.org/sgp/crs/mideast/IF10487.pdf)

${ }^{26}$ Nasuh Uslu, Türk- Amerikan İlişkileri, 21.Yüzyıl Yayınları, Ankara, 2000, s.97,98.
} 
and their own territories. As of 1947, the containment policy that the United States began to implement during the Cold War was the most important example of the change in policies that the great powers would follow. With the establishment of NATO within the Western alliance, the process has also focused on international military structures. In response to the containment and security policies of the United States, the USSR established its own security line and established the Warsaw Pact with Eastern European countries in the military and the COMECON in the economic field. ${ }^{27}$ Turkey, on the other hand, has become increasingly important within the scope of the containment policy, especially in terms of its geopolitical position. With the increasing importance, relations also began to increase. As the table shows, US aid continued despite the problems for the decade between 1953 and 1963. By the 1950s, there were significant developments in Turkish domestic politics. With the Democratic Party (DP), founded in 1946, a transition to multi-party life was realized. In 1950, when the DP won the elections, power passed from the Republican People's Party (CHP) to the DP. According to Bağc1, Turkish foreign policy in the 1950s with the DP was shaped on three basic principles. These have been i) the prevention of the spread of the Soviets, ii) military and economic cooperation with the West, and iii) the partition of Cyprus since $1955 .{ }^{28}$

Economic Aid of the USA (1948-1965)

\begin{tabular}{|c|c|c|c|c|c|c|c|c|c|c|}
\hline 1953 & 1954 & 1955 & 1956 & 1957 & 1958 & 1959 & 1960 & 1961 & 1962 & 1963 \\
\hline 46,2 & 92,3 & 68,1 & 99,9 & 96,6 & 85,7 & 103,3 & 84,4 & 101,9 & 135,0 & 130,5 \\
\hline
\end{tabular}

It can be said that Turkey's foreign policy was in rapid change during the Cold War period. At this point, the existence of Turkey's geopolitically-owned geography on the expansion routes of its northern neighbor, the Russians, and then the USSR, could be considered as an important threat. In this period, although Turkey had a dangerous neighbourly relationship with the USSR, it was seen by Westerners as far away from the central region that NATO was supposed to protect. ${ }^{29}$ However, according to Oran, four reasons stand out in Turkey's decision to join NATO. The first was the USSR's territorial claim from Turkey in 1945. The second was that the Turkish statesmen saw membership in NATO as a requirement of the foreign policy alignment towards the West. Third, there was a concern that Turkey would not receive military and economic assistance from the United States if it does not enter NATO. Finally, the Turkish public, too, saw NATO membership as an essential thing. Thus, Turkey made its application to NATO on 11 May 1950, but the application was not concluded. In the meantime, the Turkish administration, following closely the ongoing war in Korea, has decided to send troops to the

\footnotetext{
${ }^{27}$ For further details see, Merve Suna Özel Özcan, Uluslararası Alanda Imparatorlukların Hikayesi: Rusya Federasyonu Örneği, Nobel Yayıncılık, Ankara 2020.

${ }^{28}$ Hüseyin Bağcı, Türk Dş Politikasında 1950’li Yıllar, ODTÜ Yayıncılık, Ankara, 2014, s.70.

${ }^{29}$ Ali Ayata, Murat Ercan, "Soğuk Savaş Sonrası Ortaya Çıkan Bölgesel Sorunlar Bağlamında Türkiye-ABD İlişkilerinin Kazandığı Yeni Boyutlar “,Bilgi Sosyal Bilimler Dergisi, Sayı: 15, 2007 s.21.
} 
region in order to ensure its participation in NATO, following the UN's decision to send troops to Korea. ${ }^{30}$

Turkey became one of the few states to participate in the broadest and most active manner in the Korean War, which broke out on 25 June 1950, by granting a brigade of forces to the United Nations command. It was decided on 18 February 1952 that Turkey would join NATO which became an intertnatioanl gain for Turkey. Thus, Turkey took its place under NATO's "nuclear umbrella". ${ }^{31}$ Also in 1954, Turkey and US sign first status of forces agreement and agreed to joint use of what becomes Incirlik Air Base. ${ }^{32}$

In this way, Turkey established its security against the Soviet threat by acquiring not only the alliance of the United States but also the alliance of 13 other countries. At the Yalta Conference's $6^{\text {th }}$ session held on February 10, 1945, Stalin requested that the Montreux Convention on the Istanbul and Dardanelles be revised and amended. ${ }^{33}$ After Stalin's death on March 5 1953, the new Soviet leadership announced on May 30, 1953 that they had renounced their territorial claim from Turkey and their views on the common defense of The Straits. However, the USSR's position on Turkey did not create a confidence because the issue regarding base requests in the Straits was not clearly stated.

In this period, Turkey tried to maintain its security within the region through some alliance agreements with neighboring countries, and in this regard, Turkey, Greece and Yugoslavia signed a Treaty of Friendship and Cooperation on 28 February 1953 in Ankara. The Balkan alliance couldn't last for a long time and had become a dead document since Turkey and Greece falled into conflict over the Cyprus issue since 1955. After Turkey and Iraq signed the Baghdad Pact on February 24, 1955; the United Kingdom on April 4, 1955; Pakistan on September 23, 1955 and Iran on November 3, 1955 joined the Baghdad Pact. The Baghdad Pact, while seeking to play a unifying role in the Middle East and especially in the Arab generation, has divided this generation into three parts although the real intention was to prevent the USRR intervention in the Middle East. Iraqofficially announced its withdrawal from the Baghdad Pacton March 24, 1959. After the exit of Iraq, Ankara became the headquarter of the pact. The Baghdad Pact's name was changed to "Central Treaty Organization" (CENTO) on August 18, 1959..$^{34}$

While these developments were taking place on the international and regional basis, the USSR was constantly working towards having the nuclear and ballistic technology that the

\footnotetext{
${ }^{30}$ Erhan, agm. s. 543-545.

${ }^{31}$ Aliriza, Aras, age. ,s.2,3.

CRS, Turkey-U.S. Relations: Timeline and Brief Historical Context, (Erişim: https://fas.org/sgp/crs/mideast/IF10487.pdf)

${ }^{33}$ As it is known, this issue is mentioned in the Potsdam Conference minutes. Accordingly, in the afternoon session of 23 July, Stalin raised the demand for changes in The Straits transition regime and the Soviets requested a border correction for the Treaty of Alliance. In addition, there has been a demand for a base in or near the Straits. (İsmail Köse, "Sovyetler Birliği'nin Türk Boğazlarıla İlgili Talepleri:1945-1946 Notaları", Ankara Üniversitesi SBF Dergisi, Cilt: 74, Say1: 4, ss. 1127-1128)

${ }^{34}$ Uslu, age. s.111-115.
} 
United States already had. As a matter of fact, on October 4, 1957, the USSR sent Sputnik ${ }^{35}$ into space, and the United States lost its superiority in the nuclear field. The fact that the USSR built such a powerful and long-range missile strategically gave them the upper hand. ${ }^{36}$

Although it was thought that the relations between the USA and Turkey would continue without any problems in the international conjuncture before 1960, a completely opposite picture began to emerge from 1960 onwards. ${ }^{37}$ During this period, it is clearly seen that antiAmericanism had increased, that trust in the United States had decreased, and that there had been chaos in relations with the United States. At this point, the first breaking point in Turkish American relations was the deployment of missiles capable of carrying nuclear warheads named Jupiter to Turkey without being asked by the United States, making them the subject of negotiation with the USSR for the missiles in Cuba, and then dismantling the missiles.Turkey agreed with the USSR to withdraw the Soviet missiles placed in Cuba, and the United States dismantled the Jupiter missiles in Turkey in October 1962, eliminating the risk of a nuclear war. However, this development led Turkish public to believe that America would not hesitate to take decisions that would endanger Turkey's security and existence at any time. Second, it was actually considered as an indication that the United States held its own security interests above those of its allies.

\subsection{Cuban missiles crisis and changing balances: a balance of Horrors}

In 1960, there were crucial changes in Turkish political life. On May 27, 1960 the first military coup took place in Turkey and The Democratic Party rule ended. After that, elections were held in 1961. However, while these changes were taking place in Turkey's domestic politics, a period of problems was entered in Turkey's relations with the United States in the international arena. However, the most significant break was in 1957 when the Russians sent Sputnik into space. After that, US President Eisenhower decided to deploy medium-range missiles on NATO member states in Europe in order to be a deterrent against Russian nuclear power. ${ }^{38}$ However, the process has progressed as neither the United States nor Turkey had planned. Because in response to this step of the United States, the USSR did not remain unresponsive and established its own missile system in Cuba.

Looking at the process, it will be seen that relations between the USA and the USSR are not good either. Both countries were in great conflict, especially with regard to nuclear developments and Germany. In September 1960, Khrushchev began explosions of fifty megatons, ending his short-lived nuclear agreement with the United States. On the other hand, on August 13, 1961, East Germany started to build a set between them and the West. Thus the

\footnotetext{
35 "The story begins in 1952, when the International Council of Scientific Unions decided to establish July 1, 1957, to December 31, 1958, as the International Geophysical Year (IGY) because the scientists knew that the cycles of solar activity would be at a high point then. on October 4, 1957, when the Soviet Union successfully launched Sputnik I, The world's first artificial satellite was about the size of a beach ball (58 cm.or 22.8 inches in diameter), weighed only $83.6 \mathrm{~kg}$. or 183.9 pounds, and took about 98 minutes to orbit the Earth on its elliptical path. While the Sputnik launch was a single event, it marked the start of the space age and the U.S.-U.S.S.R space race.

(NASA, Sputnik and The Dawn of the Space Age, Erişim: https://history.nasa.gov/sputnik/)

${ }^{36}$ Armaoğlu,age. s.545

${ }^{37}$ Uslu, agm. s.206,207.

${ }^{38}$ Uslu,age.s.137.
} 
people and families on both sides of the wall in Berlin were torn apart. In Kissenger's statement, "the construction of The Wall showed democracies the Berlin stalemate". ${ }^{39}$ Related to Berlin Wall crisis, the struggle intensified between two superpowers that is resulted in the Cuban missile crisis. After U.S. Secretary of Defense Robert McNamara showed President Kennedy the aerial photographs of the missile bases in Cuba, President Kennedy made a speech on American radio and television on the evening of October 1962, saying that Soviet missiles had been deployed in Cuba and they could hit an area from Hudson Bay in the north to Lima in the south, which would mean a clear threat to the peace and security of all the Americas, and for this reason he called for the dismantling of these missiles. ${ }^{40}$

The inter-state relationship had such a tense atmosphere that the whole world is concerned that a Third World War could break out at any moment. During this tense period, the United Nations Secretary General U'thant ${ }^{41}$ put a serious amount of work to reconcile and pacify the United States and the USSR. Howeverin a message sent to Kennedy by Kruschev on 27 October 1962, it was argued that there were American rocket bases in Turkey. Kruschev declared that Russia would not take back its offensive weapons from Cuba if America did not withdraw these rockets from Turkey. ${ }^{42}$ The text of the message sent to Kennedy was broadcast by Radio Moscow and Kruschev stated in his message that the Soviet Union was ready to make a declaration pledging not to interfere in Turkey's internal affairs, but that the United States should make the same commitments for Cuba.

There was no mention of Jupiter missiles in Turkey in Kruschev's 28 October 1962 letter to

Volume 12

Issue 3

June

2020 Kennedy mentioning that Soviet missiles in Cuba would be removed. Kruschev's decision to dismantle its missiles in Cuba has created great relief in NATO countries. Because at the NATO Council meeting on 28 October, it was stated that if the United States attempted to invade Cuba, NATO could be dragged into war and Turkey could be subjected to a Soviet invasion in response. Some delegates at the council wanted the United States to give assurances that it would not invade Cuba, while the American delegate avoided to give assurances. ${ }^{43}$

So Kruschev's decision to dismantle the missiles without any reference to Turkey created great comfort in the council. Following the agreement between the USSR and the United States and following the prevention of a possible nuclear war, the USSR missiles based in Cuba were dismantled under the supervision of the International Red Cross on 3 November 1962. At December1962 meeting in Paris, the removal of Jupiter missiles in Turkey was agreed and the missiles were dismantled at the end of April 1963. Thus, after the Cuban crisis, the States entered the period of detante. As seen in the Cold War era, although 1962 the Cuban Missile Crisis led to a direct confrontation of the two superpowersthis risky policy ('brinkmanship')

\footnotetext{
${ }^{39}$ Henry Kissenger, Diplomasi, Çev. İbrahim H. Kurt, İşbankası Yayınları, İstanbul, 2000 s. 648- 649

${ }^{40}$ Armaoğlu,age. s.608, Uslu,age., s.151.

${ }^{41}$ After the death of UN Secretary-General Dag Hammarskjöld, U'thant was nominated by the United States and the Soviet Union as acting secretary-general and elected to that post in 1961, becoming permanent secretary-general in 1962. He was re-elected to the same post for five years in 1966. A Burmese educator, U'thant served as the third secretary-general of the United Nations from 1961 to 1971. ("U Thant", http://www.britannica.com/EBchecked/topic/590010/U-Thant)

${ }_{42}$ Milliyet, 28 Ekim 1962 (Erişim: http://gazetearsivi.milliyet.com.tr/Arsiv/1962/10/28)

${ }^{43}$ Sander, age, s.536
} 
ended in a peaceful manner can be interpreted as mutually assured destruction (mutually assured destruction - MAD) became an effective perspective to prevent tensions turning into a military confrontation between the superpowers. ${ }^{44}$

\subsection{Great Turmoil: Cyprus issue and Johnson Letter}

With the Cuban crisis, Turkish-US relations have taken a serious damage. However, the real breakdown of the relations between the two countries occurred via Cyprus. Although Turkey is seen as an important geopolitical and strategic partner for the United States, it will be seen that both countries take different positions on Cyprus. Kıbrıs meselesinin tarihsel arka planı 1878 yılına kadar uzanmaktadır. Immediately after Cyprus was granted to Britain in 1878, Greek Cypriots and Greece began attempts to implement Enosis in line with the Megali Idea. Although problems and riots followed from time to time, British rule continued in the region. In 1947, however, the process changed rapidly. Because on February 27, 1947, Greece declares to the world that "Greece should unite with Cyprus". As of 1950, the process takes on an international dimension and Turkey is involved in the process due to its historical and cultural ties on the island. ${ }^{45}$

With the Zurich and London treaties, which were carried out since 1959, the process was continued with the mutual negotiations of Britain, Turkey and Greece. However, with the attitude of the Greek Cypriots on the island and the time to live afterwards, the Cyprus issue has created a major break in Turkish foreign policy. On the other hand, the fact that Turkey is a medium-sized power in the international arena has enabled it to pursue a Cyprus policy in which it has clearly demonstrated its own power capacity and foreign policy stance, considering the steps it has taken on a regional scale. Cyprus has been perceived as a 'national cause' for Turkey and Greece for centuries due to its geographical location for Turkey and serious amount of Turkish population. While this island was so strategic both for Turkey and Greece, the basic aim of US administrations regarding the Cyprus question was to freeze the conflict and to anticipate a war between Greece and Turkey, both of whom strategically important allies of the US were. In Monteagle Stearns' analysis, the US had to deal with several risks. First, in a possible war between Turkey and Greece, NATO could be destabilized and weakened, and thus its southeastern belt could collapse. Second, the political, military, and economic cooperation between the US, Greece, and Turkey could be weakened and the presence of American base facilities in these countries could be put in danger. ${ }^{46}$

The massacres against the Turkish Cypriots started at the end of 1963 provoked great reactions in Turkey. The Turkish government's inability to intervene in Cyprus, at least ostensibly due to pressure from the American rulers, and the fact that American President Johnson sent a very harsh letter to Turkish Prime Minister Ismet Inönü to stop the Turkish intervention, which exceeded the rules of diplomatic courtesy, also had great repercussions in Turkey. The real question about the Johnson Letter is that while the United States could have

\footnotetext{
${ }^{44}$ Heywood,age s.71.

${ }^{45}$ Ulvi Keser, "21 Aralık 1963 Kanlı Noel, Kumsal Faciası Ve Bugüne Yansımaları", Çăgdaş Türkiye Tarihi Araştırmaları Dergisi, XI/23, (2011/Güz), s. 94-95.

${ }^{46}$ Atmaca, agm.s.28-29.
} 
prevented the intervention with a little warning, why it has implicated NATO, the Soviet Union and the issue of weapons use in the letter. Since the 1960s, all aspects of Turkish - American relations and Turkish Foreign Policy have been at the center of public debate. Turkey's membership in NATO and its relations with the United States have been widely questioned by the Turkish press.

Although the Turkish-Soviet relations did not lose any of their coldness in the period up to the Cyprus crisisof 1964 there were some interactions between the two states. But rather, Turkey's efforts to avoid unnecessary friction with the Soviets played a big role. ${ }^{47}$ During the Justice Party (AP) government, Turkey began to move away from the West as a result of negative events with the United States. At that time, some of the support requests of Turkey for industrial investments were rejected by the United States and the West; however, it was supported by the USSR starting in 1967. In addition to the relationship with the USSR, Turkey did not exit from NATO. ${ }^{48}$ Moreover, while Turkey developed its relations with the USSR in political and economic terms during this period, it made efforts to keep its relations with the USSR away from the ideological axis.

Upon the decision of the Greek Cypriot side to arm itself, the Turkish government announced its decision to land in Cyprus on 2 June 1964 and began the necessary preparations. Military mobility had also begun to increase in Greece and in the Republic of Cyprus. Disturbed by the developments, the United States found a possible war in the region contrary to its own strategic interests. President Johnson's famous "Johnson letter" was delivered to Turkish Prime Minister Inönü on June 5, 1964. The Johnson letter became the second disappointing incident in Turkish - American relations. Before the impacts of the result of the Cuban crisis concluded, the United States left Turkey alone again for its own interests. The letter was written in a very harsh and vulgar manner and contained humiliating statements. The letter has been hidden from the public for some time. In the "Johnson Letter" the alliance between Turkey and the United States was mentioned, and it has been stated that Turkey cannot take such a decision without consulting the United States. It has been said that it must act in consultation with other countries that are parties to the Treaty of Guarantee for intervention. The most important part of the letter "if Turkey intervenes in Cyprus, the USSR will probably enter into the problem. In any attack by the USSR on Turkey, NATO countries may not be under any obligation to defend Turkey" was this statement. In addition, the United States added that it would not consider it appropriate that Turkey to use any weapons or military products it has purchased from the USA during its campaign on the island. ${ }^{49}$ Thus, the United States, which we risk all kinds of dangers for and which we are always be with, warned Turkey that

\footnotetext{
${ }^{47}$ Sander, age. s. 821

48 Baskın Oran, “Göreli Özerklik-3”, Ed. Baskın Oran Türk Dış Politikası (Cilt1 1919-1980), İletişim Yayınları, İstanbul, 2009, s.676.

49 Armaoğlu, age s.789; Oran, agm. s.686; Nasuh Uslu “Türkiye ABD ilişkileri”, ed. Haydar Çakmak, Türk Dış Politikası, 1919-2008, Platin Yayınları, Ankara, 2009, ss 690-695
} 
Turkey would be left alone in the political arena in the event of a military operationextraction. That was the key point in the Johnson Letter. ${ }^{50}$

Prime Minister Inönü responded to Johnson's letter on 13 June. That answer bore a rather soft expression. ${ }^{51}$ This reply sent by Ismet Inönü to US President Johnson is longer and more comprehensible than Johnson's letter. Although Ismet Inönü did not use very harsh statements, he expressed his resentment. Turkey was one of the most loyal allies of the United States in the region. As a "friendly ally" Turkey has drawn the profile of a state that tries to fulfill every request of Washington. After the questioning process created by the Cuba crisis and the Johnson Letter issue, Turkey has moved away from its single-center aid policy and its endless reliance on the Western Bloc, and has taken important steps to pursue a more flexible foreign policy, albeit within the Western Bloc. While the Cuban Missile Crisis is a wide-ranging one that concerns the international community, Turkey has seen the rapid displacement of US's allies and enemies when it comes to its own interests. The second breaking point in Turkish-US relations after the Cuban crisis has been with the Cyprus issue and the Johnson letter. As related to this Fahir Armaoğlu said that "how Truman Doctrine, March June 12, 1947, was a turning point in Turkish - American relations, the Johnson Letter of June 5, 1964 was a turning point in reversing a solid era of the Truman Doctrine also". Indeed, the Johnson Letter has changed the way the Turkish people and statesmen view the United States. ${ }^{52}$

On the other hand, after the Justice Party came to power at the end of 1965, leftist groups started to direct intense and critical approaches to Turkey's relationswith NATO and the U.S. All aspects of Turkish-American relations, especially newspaper writers and academics, and especially military contacts has been taken under scrutiny. On the other hand, the problem of opium poppy was raised between the two countries when the Turkish government again allowed the cultivation of opium poppyin June 1974. The decision of the Turkish government was seen as a decision taken directly against the United States. While the US Congress feeling the need to retaliate, was preparing and discussing draft laws to cut off American aid to Turkey, the military coup in Cyprus on 14 July and the subsequent intervention of Turkey on the island turned the course of events into another direction. ${ }^{53}$

\footnotetext{
${ }^{50}$ Metin Toker, “Demokrasimizin İsmet Paşalı Yılları, İnönü’nün Son Başbakanlığı 1961-1965”, Bilgi Yayınevi, İstanbul 1992, s.204-207.

${ }^{51}$ The "writing style and content" of the letter has been "disappointing" for Turkey, an ally of the United States.

* Along with this last attempt, this is the fourth need for military intervention in Cyprus since the end of 1963, and Turkey has been in consultation with America since the beginning of this issue.

- The Greek Cypriot government has openly taken up arms, engaged in unconstitutional activities, increased its "tyranny" against the Turks, and all this has been supported by Greece, even though it is against the international treaties it has signed, but despite all the warnings of Turkey, America has not done anything.

- Can there be any mention of an alliance between states that rejects their obligations and responsibilities arising from treaties against each other at any time?

- "An attack on any of the NATO allies will always be justified by the aggressor in its nature. If NATO's structure is weak enough to deal with the aggressor's claims, it is indeed in need of treatment."

* According to Turkey's understanding, NATO obliges immediate assistance to a member who is attacked. What is left to the discretion of the members is the nature and extent of the assistance" (Armaoğlu, age., s. 790)

${ }^{52}$ Armaoğlu,age. s.789

${ }^{53}$ Uslau, agm. s.216,217., Uslu,age. s.223-233
} 
Throughout the 1980s, American leaders continued to attribute great strategic importance to Turkey. Although Turkey was considered as a southern wing country along with Spain and Portugal within the framework of NATO, it was important actually for the Americans to be a stepping stone in establishing influence in the Middle East region or an obstacle in preventing other superpower's influence. Turkey was the main obstacle for the USSR to spread its influence to the Middle East, and the provider of the Eastern Mediterranean balance to the advantage of the West by imprisoning Soviet naval power in the Black Sea. The Iranian Revolution, the invasion of Afghanistan by the USSR and the uncertainties in the Middle East countries made Turkey a thoroughly indispensable state for the United States. ${ }^{54}$

As can be seen, Turkey has been looking for new alternatives due to the crises and problems it experienced during the Cold War period. The strategic partnership discourse between the two countries, which is constantly expressed in the background, seeks to create an atmosphere of acceptance of hegemon power, which is intended to be shaped according to the interests of the one side.

\section{Conclusions}

The relations between the US and Ottoman were mainly conducted based on economic and trade field. With the dissolution of the Ottoman, Turkey as a new nation-state had to design its foreign policy agenda with the US. In this relationship, although economic relations were also considerably important it is possible to argue that the main character of the relations were defined in terms of strategic and political issues. The Cold War structure had a direct impact on the nature of relations. During the Cold War period, the Soviets were seen as enemies and the West as friends for Turkey. The expression of realism that "there are no friendships and hostilities in international politics, there are only interests" has been formulated as "friendships and hostilities define our interests" by the social constructivism. In this context, it is possible to highlight the word "interest" when evaluating the relations between Turkey and the United States. Because the change in the use of friend-enemy concepts justifies the interest-axis readings. Therefore, the broad definition of the Western identity including Turkey, which was shaped by security practices and ideology during the Cold War helped Turkey develop its relations with the West. There is no doubt that Turkey's geopolitical position was an important factor that facilitated its involvement in the Western alliance during the Cold War. However, it is clear that Turkey has tried to develop alternative policies during troubled times with the United States.

\section{Kaynakça:}

ALIRIZA Bulent; ARAS, Bulent, U.S.-Turkish Relations A Review at the Beginning of the Third Decade of the Post-Cold War Era, CSIS, November 2012ARMAOĞLU, Fahir, 20. Yüzyıl Siyasi Tarihi, Alkım Yayınları, 2005

ATMACA, Ayşe Ömür, "The Geopolitical Origins of Turkish-American Relations: Revisiting the Cold War Years", All Azimuth, Vol.3, No.1, Jan. 2014

\footnotetext{
${ }^{54}$ Uslu, agm, .s.219
} 
An Analysis of Turkish-American Relations from a Historical Perspective

AYATA, Ali; ERCAN Murat, "Soğuk Savaş Sonrası Ortaya Çıkan Bölgesel Sorunlar Bağlamında Türkiye-ABD İlişkilerinin Kazandığı Yeni Boyutlar “,Bilgi Sosyal Bilimler Dergisi , Say1: 15, 2007, ss. 18-22.

BAĞCI, Hüseyin, Türk Dş Politikasında 1950'li Yıllar, ODTÜ Yayıncılık, Ankara, 2014

BOSTANOĞLU, Burcu, “Amerika ve Osmanlı’nın Akdeniz'de Başlayan Seyir Defteri”, Doğu Batı Yayınları, Sayı: 42, 2007.

Türkiye-ABD İlişkilerinin Politikası, İmge Kitabevi, Ankara, 2008

ÇELIK, Hatice, "Middle Power Theory Literature: The Case of South Korea", I. Uluslararası Insan Ve Toplum Bilimleri Kongresi Kitabl, Ankara, 2017.

ÇETIN, Atilla Garp Ocakları, İslam Ansiklopedisi, (Erişim: https://islamansiklopedisi.org.tr/garp-ocaklari)

EKİNCIKLİ, Mustafa, İnönü-Bayar Dönemleri Türk Dış Siyaseti, Berikan Yayınları, 2001

ERHAN, Çağrı, Türk-Amerikan İlişkilerinin Tarihsel Kökenleri, İmge Kitabevi, Ankara.

"Ottoman Official Attitudes towards American Missionaries", (Erişim:http://intcommunity.org/wpcontent/uploads/2018/02/Ottoman_Official_Attitudes-Cagri_Erhan.pdf)

“ABD ve NATO'yla İlişkiler”, Ed. Baskın Oran Türk Dış Politikası (Cilt1 1919-1980), İletişim Yayınları, İstanbul, 2009

GÖNLÜBOL, Mehmet, Uluslararası Politika, AÜSBF Yayınları, Ankara, (3. Baskı) 1985

KESER, Ulvi, “21 Aralık 1963 Kanlı Noel, Kumsal Faciası Ve Bugüne Yansımaları”, Çağdaş Türkiye Tarihi Araştırmaları Dergisi, XI/23, (2011/Güz)

KISSENGER, Henry, Diplomasi, Çev. İbrahim H. Kurt, İstanbul: İşbankası Yayınları, 2000.

KÖSE, İsmail, "Sovyetler Birliği'nin Türk Boğazlarıyla İlgili Talepleri: 1945-1946 Notaları", Ankara Üniversitesi SBF Dergisi, Cilt: 74, Sayı: 4

ORAN, Baskın, “Türk Dış Politikasının Teori ve Pratiğì”, Ed. Baskın Oran Türk Dış Politikası (Cilt1 1919-1980), İletişim Yayınları, İstanbul, 2009.

“Göreli Özerklik-3”, Ed. Baskın Oran Türk Dış Politikası (Cilt1 1919-1980), İletişim Yayınları, İstanbul, 2009

ÖZEL ÖZCAN, Merve Suna, Uluslararası Alanda Imparatorluklartn Hikayesi: Rusya Federasyonu Örneği, Nobel Yayınc1lı, Ankara, 2020.

SANDER, Oral, Siyasi Tarih 1914-1994, İmge Kitabevi, 2005

TOKER, Metin, Demokrasimizin İsmet Paşalı Yılları, İnönü’nün Son Başbakanlı̆̆ 1961-1965, Bilgi Yayınevi, İstanbul, 1992. TURGAY A. Üner, "Ottoman- American Trade Durıng The Nineteenth Century", Ed. Halilı İnalcık - Nejat Göyünç Heath W. Lowry, The Journal Of Ottoman Studies III,İstanbul,1982 
USLU, Nasuh, “1947'den Günümüze Türk-Amerikan İlişkilerinin Genel Portresi”, Avrasya Dosyası ABD Özel Sayısl, (Erişim: https://www.21yyte.org/assets/uploads/files/203232\%20nasuh\%20uslu.PDF)

Türk- Amerikan İlişkileri, 21. Yüzyı1 Yayınları, Ankara, 2000

Türkiye ABD ilişkileri”, ed. Haydar Çakmak, Türk Dış Politikası, 1919-2008, Ankara, Platin Yayınları, 2009

\section{İnternet Kaynakları:}

CRS, "Turkey-U.S. Relations: Timeline and Brief Historical Context”, (Erişim: https://fas.org/sgp/crs/mideast/IF10487.pdf)

Milliyet, 28 Ekim 1962 (Erişim: http://gazetearsivi.milliyet.com.tr/Arsiv/1962/10/28)

NASA, Sputnik and The Dawn of the Space Age, Erişim: https://history.nasa.gov/sputnik/

\section{"U Thant"}

(Erişim:http://www.britannica.com/EBchecked/topic/590010/U-Thant)

"WASP", (Erişim: https://dictionary.cambridge.org/tr/s\%C3\%B6zl\%C3\%BCk/ingilizce/wasp) 